\title{
Chronology of 1950s American Culture
}




\begin{tabular}{|c|c|c|c|c|}
\hline Date & Events & Criticism & Literature & Performance \\
\hline 1950 & $\begin{array}{l}\text { Alger Hiss convicted } \\
\text { of perjury (January). } \\
\text { Joseph McCarthy } \\
\text { begins anticommunist } \\
\text { crusade (February). } \\
\text { Korean War (June } \\
\text { 1950-July 1953). } \\
\text { Albert Einstein } \\
\text { discovers the general } \\
\text { theory of gravitation. } \\
\text { Charles Schulz's } \\
\text { Peanuts comic makes }\end{array}$ & $\begin{array}{l}\text { Bruno Bettleheim, } \\
\text { Love is not Enough } \\
\text { Erik Erikson, } \\
\text { Childhood and } \\
\text { Society } \\
\text { Haywood Patterson, } \\
\text { Scottsboro Boy } \\
\text { David Riesman, The } \\
\text { Lonely Crowd } \\
\text { Lionel Trilling, The } \\
\text { Liberal Imagination }\end{array}$ & $\begin{array}{l}\text { Paul Bowles, The } \\
\text { Delicate Prey } \\
\text { Ray Bradbury, The } \\
\text { Martian Chronicles } \\
\text { Charles Olson, } \\
\text { 'Projective Verse' } \\
\text { Conrad Richter, The } \\
\text { Town } \\
\text { Micky Spillane, My } \\
\text { Gun Is Quick }\end{array}$ & $\begin{array}{l}\text { William Inge, Come } \\
\text { Back, Little Sheba } \\
\text { Call Me Madam } \\
\text { (644 performances) } \\
\text { Guys and Dolls } \\
\text { (1,200 performances) } \\
\text { The Member of the } \\
\text { Wedding (501 } \\
\text { performances) } \\
\text { South Pacific wins } \\
\text { Pulitzer Prize for } \\
\text { Drama }\end{array}$ \\
\hline
\end{tabular}

1951 American Committee

Hannah Arendt, The

Origins of

Totalitarianism

Rachel Carson, The

Sea Around Us

George Kennan,

American

Diplomacy

Marshall McLuhan,

The Mechanical

Bride

C. Wright Mills, White Collar
Langston Hughes, Montage of a Dream Deferred

James Jones, From

Here to Eternity

Carson McCullers,

The Ballad of the

Sad Café

Norman Mailer,

Barbary Shore

J. D. Salinger, The

1953).

Selective Service Bill

lowers draft age to

eighteen-and-a-half.

Transcontinental

television launched

(September).

Catcher in the Rye
The King and I

(1,246 performances)

Merce Cunningham, Sixteen Dances for

Soloist and

Company of Three

Lillian Hellman, The

Autumn Garden

Tennessee Williams,

The Rose Tattoo

Public launch of the

Living Theatre 


\begin{tabular}{|c|c|c|c|}
\hline Film & Television & Music & Art \\
\hline $\begin{array}{l}\text { All About Eve (Joseph } \\
\text { L. Mankiewicz) } \\
\text { The Asphalt Jungle } \\
\text { (John Huston) } \\
\text { The Big Lift } \\
\text { (George Seaton) } \\
\text { I Married a } \\
\text { Communist (Robert } \\
\text { Stevenson) } \\
\text { Sunset Boulevard } \\
\text { (Billy Wilder) }\end{array}$ & $\begin{array}{l}\text { Your Show of Shows } \\
\text { (1950-4) } \\
\text { The Cisco Kid (1950-6) } \\
\text { Racket Squad (1950-3) } \\
\text { What's My Line } \\
\text { (1950-7) } \\
\text { Your Hit Parade } \\
\text { (1950-9) }\end{array}$ & $\begin{array}{l}\text { Gordon Jenkins with } \\
\text { The Weavers, } \\
\text { 'Goodnight Irene' } \\
\text { Moon Mulligan, 'I'll } \\
\text { Sail My Ship' } \\
\text { Muddy Waters, } \\
\text { 'Rolling Stone' } \\
\text { Hank Williams, 'Cold, } \\
\text { Cold Heart' } \\
\text { People's Artists launch } \\
\text { magazine Sing Out! }\end{array}$ & $\begin{array}{l}\text { Franz Klein, Chief } \\
\text { Willem de Kooning, } \\
\text { Excavation } \\
\text { Rico Lebrun, } \\
\text { Crucifixion Triptych } \\
\text { Jackson Pollock, } \\
\text { Autumn Rhythm, } \\
\text { Lavender Mist and } \\
\text { Mural on Indian Red } \\
\text { Ground } \\
\text { Barnett Newman's first } \\
\text { solo exhibition }\end{array}$ \\
\hline
\end{tabular}

An American in Paris (Vincente Minnelli) The Day the Earth Stood Still (Robert Wise)

$I$ Was a Communist for the FBI (Gordon

Douglas)

Strangers on a Train

(Alfred Hitchcock)

A Streetcar Named

Desire (Elia Kazan)
The Amos ' $n$ ' Andy

Show (1951-3)

Boston Blackie

(1951-3)

Dragnet (1951-9)

I Love Lucy (1951-7)

Red Skelton Show

(1951-71)
Tony Bennett, 'Because of You' and 'Cold,

Cold Heart'

Jackie Brenston,

'Rocket "88"'

Nat King Cole,

'Unforgettable'

Perry Como, 'If'

The Weavers, 'On Top

of Old Smokey'
Barnett Newman,

Adam

Irene Rice Pereira,

Light is Gold

Mark Rothko, Black,

Pink and Yellow over

Orange

Hale Woodruff, The

Art of the Negro

(1950-1)

Robert Rauschenberg's

first solo exhibition 


\begin{tabular}{|c|c|c|c|c|}
\hline Date & Events & Criticism & Literature & Performance \\
\hline 1952 & $\begin{array}{l}\text { Dwight D. } \\
\text { Eisenhower (Rep) } \\
\text { runs against Adlai } \\
\text { Stevenson (Dem) in } \\
\text { presidential campaign. } \\
\text { First US hydrogen } \\
\text { bomb detonated, at } \\
\text { Eniwetok in the } \\
\text { Pacific. } \\
\text { Paul Robeson } \\
\text { awarded the Stalin } \\
\text { Peace Prize. } \\
\text { UFO sightings across } \\
\text { the country. } \\
\text { Hasbro's Mr Potato } \\
\text { Head first child's toy } \\
\text { advertised on TV. }\end{array}$ & $\begin{array}{l}\text { Aaron Copland, } \\
\text { Music and the } \\
\text { Imagination } \\
\text { Reinhold Niebuhr, } \\
\text { The Irony of } \\
\text { American History } \\
\text { 'Our Country and } \\
\text { Our Culture', } \\
\text { Partisan Review } \\
\text { Norman Vincent } \\
\text { Peale, The Power of } \\
\text { Positive Thinking } \\
\text { Paul Tillich, The } \\
\text { Courage to Be }\end{array}$ & $\begin{array}{l}\text { Ralph Ellison, } \\
\text { Invisible Man } \\
\text { Ernest Hemingway, } \\
\text { The Old Man and } \\
\text { the Sea } \\
\text { Flannery O'Connor, } \\
\text { Wise Blood } \\
\text { Micky Spillane, } \\
\text { Kill Me Deadly } \\
\text { John Steinbeck, } \\
\text { East of Eden }\end{array}$ & $\begin{array}{l}\text { Cage-Rauschenberg } \\
\text { Happening in Black } \\
\text { Mountain College } \\
\text { Pal Joey (revival, } 542 \\
\text { performances) } \\
\text { George Axelrod, } \\
\text { The Seven Year Itch } \\
\text { Tennessee Williams's } \\
\text { Summer and Smoke } \\
\text { revived Off } \\
\text { Broadway }\end{array}$ \\
\hline
\end{tabular}

1953 Dwight Eisenhower's inauguration as thirty-fourth

Daniel Boorstin, The Genius of American Politics President (January). Execution of Julius and Ethel Rosenberg for espionage (June). Josef Stalin dies (March).

Elizabeth II's coronation (June). Cinemascope and 3-D film introduced. Playboy magazine founded; Marilyn Monroe is first centrefold (December).
Sidney Hook, Heresy, YesConspiracy, No! Alfred Kinsey, Sexual Behavior in the Human Female B. F. Skinner, Science and Human Behavior Leo Strauss, Natural Right and History
James Baldwin, Go Tell It On the Mountain

Saul Bellow, The Adventures of Augie March

William Burroughs, Junkie (republished as Junky, 1964)

Richard Wright, The

Outsider

Lawrence

Ferlinghetti opens

City Lights

Bookshop
Robert Anderson, Tea and Sympathy William Inge, Picnic Arthur Miller, The Crucible Tennessee Williams, Casino Real Can-Can (892 performances) 


\begin{tabular}{llll}
\hline Film & Television & Music & Art \\
\hline $\begin{array}{l}\text { The Bad and the } \\
\text { Beautiful (Vincente }\end{array}$ & $\begin{array}{l}\text { The Adventures of } \\
\text { Ozzie and Harriet } \\
\text { Minnelli) }\end{array}$ & $\begin{array}{l}\text { Karen Chandler, } \\
\text { 'Hold Me, Thrill Me, }\end{array}$ & $\begin{array}{l}\text { Willem de Kooning, } \\
\text { Koman I (1950-2) }\end{array}$ \\
$\begin{array}{l}\text { High Noon (Fred } \\
\text { Zinnemann) }\end{array}$ & $\begin{array}{l}\text { Dragnet (1952-9) } \\
\text { Four Star Playhouse }\end{array}$ & $\begin{array}{l}\text { Lloyd Price, 'Lawdy, } \\
\text { Miss Clawdy' }\end{array}$ & $\begin{array}{l}\text { Robert Rosenberg, } \\
\text { American Action }\end{array}$ \\
Limelight (Charles & $(1952-6)$ & Johnnie Ray, 'Cry' & Andy Warhol's first \\
Chaplin) & Our Miss Brooks & Harry Smith's & solo exhibition \\
My Son Jobn (Leo & $(1952-6)$ & Folkways Anthology & The photographic \\
McCarey) & This is Your Life & Sun label launched by & quarterly Aperture \\
Singin' in the Rain & $(1952-61)$ & Sam Phillips & established \\
(Gene Kelly and & & & 'Diogenes with a \\
Stanley Donan) & & & Camera' exhibition, \\
& & & MoMA
\end{tabular}

$\begin{array}{ll}\begin{array}{l}\text { All I Desire } \\ \text { (Douglas Sirk) }\end{array} & \begin{array}{l}\text { The Liberace Show } \\ (1953-6)\end{array} \\ \text { House of Wax } & \text { The Life of Riley } \\ \text { (André De Toth) } & (1953-8) \\ \text { Niagara (Henry } & \text { Marty (Goodyear } \\ \text { Hathaway) } & \text { Television Playhouse) } \\ \text { Pickup on South Street } & \begin{array}{l}\text { Person to Person } \\ \text { (Sam Fuller) }\end{array} \\ \text { The Wild One (Laslo } & \text { Private Secretary } \\ \text { Benedek) } & (1953-7)\end{array}$

All I Desire

(Douglas Sirk)

House of Wax

(André De Toth)

Niagara (Henry

Pickup on South Street

(1953-7)
Tony Bennett, 'Rags to

Riches'

Bill Haley, 'Crazy Man

Crazy'

Big Mama Thornton,

'Hound Dog'

Lawrence Welk, 'Oh

Happy Day'

Hank Williams, 'Your

Cheatin' Heart'

Robert Rauschenberg, Erased de Kooning

Drawing

Larry Rivers repaints

Washington Crossing the Delaware

Richard Stankiewicz, Warrior (1952-3)

Life magazine starts

using colour

Stacked and stiletto heels in fashion 


\begin{tabular}{|c|c|c|c|c|}
\hline Date & Events & Criticism & Literature & Performance \\
\hline 1954 & $\begin{array}{l}\text { Senate censures } \\
\text { McCarthy following } \\
\text { Army-McCarthy } \\
\text { hearings (April-June) } \\
\text { televised live on ABC. } \\
\text { US Supreme Court } \\
\text { rules school } \\
\text { segregation } \\
\text { unconstitutional } \\
\text { following Brown v. } \\
\text { the Board of } \\
\text { Education. } \\
\text { Eisenhower signs bill } \\
\text { outlawing the } \\
\text { Communist Party. } \\
\text { US tests hydrogen } \\
\text { bomb at Bikini Atoll } \\
\text { in the Pacific. } \\
\text { Comics Code set up } \\
\text { after the publication } \\
\text { of Frederic Wertham's } \\
\text { Seduction of the } \\
\text { Innocent. }\end{array}$ & $\begin{array}{l}\text { Malcolm Cowley, } \\
\text { The Literary } \\
\text { Situation } \\
\text { David Potter, } \\
\text { People of Plenty } \\
\text { David Riesman, } \\
\text { Individualism } \\
\text { Reconsidered } \\
\text { Irving Howe founds } \\
\text { political magazine } \\
\text { Dissent } \\
\text { W. K. Wimsatt, The } \\
\text { Verbal Icon }\end{array}$ & $\begin{array}{l}\text { Raymond Chandler, } \\
\text { The Long Goodbye } \\
\text { Allen Ginsberg, The } \\
\text { Green Automobile } \\
\text { Evan Hunter, The } \\
\text { Blackboard Jungle } \\
\text { Anais Nin, A Spy in } \\
\text { the House of Love } \\
\text { Theodore Roethke, } \\
\text { Collected Poems }\end{array}$ & $\begin{array}{l}\text { John Cage's } \\
\text { happening at Black } \\
\text { Mountain College } \\
\text { House of Flowers } \\
\text { (Truman Capote and } \\
\text { Harold Arlen) } \\
\text { The Pajama Game } \\
\text { (1,063 performances) } \\
\text { Peter Pan (Edwin } \\
\text { Lester and Jerome } \\
\text { Robbins) } \\
\text { Revival of Brecht } \\
\text { and Weill's The } \\
\text { Threepenny Opera }\end{array}$ \\
\hline
\end{tabular}

W. H. Auden, The Shield of Achilles William Gaddis, The Recognitions

Lawrence

Ferlinghetti, Pictures of the Gone World Flannery O'Connor, $A$ Good Man is

Hard to Find

Sloane Wilson, The

Man in the Gray

Flannel Suit

\author{
Michael Vincente \\ Gazzo, A Hatful of \\ Rain \\ Paul Goodman's \\ The Young Disciple \\ produced by the \\ Living Theatre Off \\ Broadway \\ William Inge, \\ Bus Stop \\ Arthur Miller, $A$ \\ View from a Bridge \\ (revised 1956) \\ Tennessee Williams, \\ Cat on a Hot Tin \\ Roof
}




\begin{tabular}{|c|c|c|c|}
\hline Film & Television & Music & Art \\
\hline $\begin{array}{l}\text { From Here to Eternity } \\
\text { (Fred Zinnemann) } \\
\text { On the Waterfront } \\
\text { (Elia Kazan) } \\
\text { Rear Window (Alfred } \\
\text { Hitchcock) } \\
\text { Roman Holiday } \\
\text { (William Wyler) } \\
\text { Them! (Gordon } \\
\text { Douglas) }\end{array}$ & $\begin{array}{l}\text { Disneyland (1954-8) } \\
\text { The Adventures of Rin } \\
\text { Tin Tin (1954-9) } \\
\text { Father Knows Best } \\
\text { (1954-3) } \\
\text { Lassie (1954-71) } \\
\text { CBS See It Now } \\
\text { documentary on } \\
\text { McCarthy (March) }\end{array}$ & $\begin{array}{l}\text { Rosemary Clooney, } \\
\text { 'Mambo Italiano' } \\
\text { Doris Day, } \\
\text { 'Secret Love' } \\
\text { Elvis Presley, 'That's } \\
\text { All Right (Mama)' } \\
\text { Frank Sinatra, Songs } \\
\text { for Young Lovers } \\
\text { Newport Jazz Festival } \\
\text { established, Rhode } \\
\text { Island }\end{array}$ & $\begin{array}{l}\text { Stan Brakhage, } \\
\text { Desistfilm } \\
\text { Mark Rothko, Ochre } \\
\text { and Red on Red } \\
\text { Richard Stankiewicz, } \\
\text { Middle-Aged Couple } \\
\text { Esther Bubley first } \\
\text { female recipient of } \\
\text { Photography Magazine } \\
\text { grand prize } \\
\text { Six Gallery opens in } \\
\text { San Francisco }\end{array}$ \\
\hline
\end{tabular}

\begin{tabular}{|c|c|c|c|}
\hline $\begin{array}{l}\text { All That Heaven } \\
\text { Allows (Douglas Sirk) } \\
\text { The Blackboard Jungle } \\
\text { (Richard Brooks) } \\
\text { Invasion of the Body } \\
\text { Snatchers (Don Siegel) } \\
\text { The Man with the } \\
\text { Golden Arm (Otto } \\
\text { Preminger) } \\
\text { Rebel Without a Cause } \\
\text { (Nicholas Ray) }\end{array}$ & $\begin{array}{l}\text { Alfred Hitchcock } \\
\text { Presents (1955-65) } \\
\text { Cheyenne (1955-63) } \\
\text { Ed Sullivan Show } \\
\text { (1955-71) } \\
\text { The Honeymooners } \\
\text { (1955-6) } \\
\text { The Mickey Mouse } \\
\text { Club (1955-9) }\end{array}$ & $\begin{array}{l}\text { Chuck Berry, } \\
\text { 'Maybelline' } \\
\text { Fats Domino, 'Ain't } \\
\text { That A Shame' } \\
\text { Bill Haley and his } \\
\text { Comets, 'Rock Around } \\
\text { the Clock' } \\
\text { Alan Freed's first Rock } \\
\text { 'n' Roll Party stage } \\
\text { show } \\
\text { Following performance } \\
\text { of 'Around Midnight' } \\
\text { at Newport, Miles } \\
\text { Davis joins quintet } \\
\text { with John Coltrane }\end{array}$ & $\begin{array}{l}\text { Ray Johnson, } \\
\text { Elvis collages } \\
\text { Jasper Johns, Flag and } \\
\text { White Flag } \\
\text { Franz Kline, } \\
\text { White Forms } \\
\text { Robert Rauschenberg, } \\
\text { Rebus } \\
\text { 'The Family of Man' } \\
\text { exhibition, MoMA }\end{array}$ \\
\hline
\end{tabular}




\begin{tabular}{|c|c|c|c|c|}
\hline Date & Events & Criticism & Literature & Performance \\
\hline 1956 & $\begin{array}{l}\text { Eisenhower elected } \\
\text { for second term } \\
\text { (beating Stevenson). } \\
\text { Suez crisis in Egypt. } \\
\text { Soviet Union invades } \\
\text { Hungary (October). } \\
\text { Antineutron } \\
\text { discovered at the } \\
\text { University of } \\
\text { California. } \\
\text { Federal and Interstate } \\
\text { Highway Act } \\
\text { authorizes } \\
\text { construction of } \\
\text { interstate highways. }\end{array}$ & $\begin{array}{l}\text { Felix Frankfurter, } \\
\text { Law and Men } \\
\text { Dwight Macdonald, } \\
\text { The Ford } \\
\text { Foundation } \\
\text { C. Wright Mills, The } \\
\text { Power Elite } \\
\text { William Whyte, The } \\
\text { Organization Man }\end{array}$ & $\begin{array}{l}\text { James Baldwin, } \\
\text { Giovanni's Room } \\
\text { Saul Bellow, Seize } \\
\text { the Day } \\
\text { Elizabeth Bishop, } \\
\text { North and South } \\
\text { and A Cold Spring } \\
\text { Allen Ginsberg, } \\
\text { Howl and Other } \\
\text { Poems } \\
\text { Grace Metalious, } \\
\text { Peyton Place }\end{array}$ & $\begin{array}{l}\text { Bells are Ringing } \\
\text { (924 performances) } \\
\text { My Fair Lady (2,717 } \\
\text { performances) } \\
\text { Samuel Beckett, } \\
\text { Waiting for Godot } \\
\text { (from Paris) } \\
\text { Eugene O'Neill, } \\
\text { Long Day's Journey } \\
\text { into Night } \\
\text { performed } \\
\text { Tennessee Williams, } \\
\text { Sweet Bird of Youth }\end{array}$ \\
\hline
\end{tabular}

1957 School desegregation

Rock, Arkans

Martin Luther King

$\mathrm{Jr}$ elected as first

leader of Southern

Christian Leadership

Conference (SCLC).

Civil Rights Act (first

successful civil rights

bill since 1875).

USSR launches

Sputnik 1 (October)

and Sputnik 2

(November).

US Surgeon General reports link between cigarette-smoking and lung cancer.
Irving Howe,

Politics and the

Novel

Dwight Macdonald,

Memoirs of a

Revolutionist

Norman Mailer,

'The White Negro'

Richard Wright,

White Man Listen!

Vance Packard, The

Hidden Persuaders
Jack Kerouac, On

the Road

Bernard Malamud,

The Assistant

Vladimir Nabokov,

Pnin

Frank O'Hara,

Meditations in an

Emergency

Dr Seuss, The Cat in

the Hat
William Inge, The Dark at the Top of

the Stairs

Eugene O'Neill, $A$

Moon for

Misbegotten first

performed

John Osborne, Look

Back in Anger (from

London)

West Side Story 732

performances) 


\begin{tabular}{|c|c|c|c|}
\hline Film & Television & Music & Art \\
\hline $\begin{array}{l}\text { Bus Stop (Joshua } \\
\text { Logan) } \\
\text { The Man in the Gray } \\
\text { Flannel Suit (Nunnelly } \\
\text { Johnson) } \\
\text { Moby Dick (John } \\
\text { Huston) } \\
\text { The Searchers (John } \\
\text { Ford) } \\
\text { The Ten } \\
\text { Commandments } \\
\text { (Cecil B. DeMille) }\end{array}$ & $\begin{array}{l}\text { Steve Allen Show } \\
\text { (1956-60) } \\
\text { The Price is Right } \\
\text { (1956-65) } \\
\text { To Tell the Truth } \\
\text { (1956-68) } \\
\text { Trenty-One (1956-8) } \\
\text { Mass release of } \\
\text { pre-1948 films to } \\
\text { television }\end{array}$ & $\begin{array}{l}\text { American Banjo- } \\
\text { Three-Finger and } \\
\text { Scruggs Style } \\
\text { Johnny Cash, 'I Walk } \\
\text { the Line' and Folsom } \\
\text { Prison Blues } \\
\text { Elvis Presley, } \\
\text { 'Heartbreak Hotel' and } \\
\text { Elvis Presley } \\
\text { Little Richard, 'Tutti } \\
\text { Frutti' } \\
\text { Gene Vincent, 'Be Bop } \\
\text { a Lula' }\end{array}$ & $\begin{array}{l}\text { William Klein, } \\
\text { New York } \\
\text { Gordon Parks, Black } \\
\text { Graveyard } \\
\text { Jackson Pollock killed } \\
\text { in car crash (August) } \\
\text { Marcel Breuer designs } \\
\text { Whitney Museum of } \\
\text { American Art }\end{array}$ \\
\hline
\end{tabular}

\section{The Incredible}

Shrinking Man (Jack

Arnold)

Peyton Place (Mark

Robson)

Raintree County

(Edward Dmytryk)

The Three Faces of Eve

(Nunnally Johnson)

12 Angry Men (Sidney

Lumet)
Dick Clark's American Fats Domino,

Bandstand (1957-89)

Leave It to Beaver

(1957-63)

Perry Mason (1957-66)

The Real McCoys

(1957-63)

Richard Diamond,

Private Detective

(1957-60)
'Blueberry Hill'

Sam Cooke, 'You Send

$\mathrm{Me}$

Buddy Holly, 'Peggy

Sue'

Jerry Lee Lewis, 'Great

Balls of Fire'

Elvis Presley, 'All

Shook Up' and

'Jailhouse Rock'
Robert Rauschenberg,

Factor I and Factor II

W. Eugene Smith's major photographic study of Pittsburgh

Aaron Siskind photographs human feet

Wallace Berman opens

Ferus Gallery, Los

Angeles

Leo Castelli’s Gallery opens in New York 


\begin{tabular}{|c|c|c|c|c|}
\hline Date & Events & Criticism & Literature & Performance \\
\hline 1958 & $\begin{array}{l}\text { US launch Explorer } 1 \\
\text { (February) and } \\
\text { Vanguard } 1 \text { (March) } \\
\text { satellites into orbit. } \\
\text { Elvis Presley drafted } \\
\text { into the US Army. } \\
\text { Worst recession since } \\
\text { World War II. } \\
\text { Wham-O’s \$1.98 } \\
\text { Hula-Hoop was the } \\
\text { summer craze. } \\
\text { First skateboard, } \\
\text { invented in Dana } \\
\text { Point, California. }\end{array}$ & $\begin{array}{l}\text { Hannah Arendt, The } \\
\text { Human Condition } \\
\text { John Kenneth } \\
\text { Galbraith, The } \\
\text { Affluent Society } \\
\text { Martin Luther King } \\
\text { Jr, Stride Toward } \\
\text { Freedom } \\
\text { Martin Mayer, } \\
\text { Madison Avenue } \\
\text { U.S.A. } \\
\text { Paul Robeson, Here } \\
\text { I Stand }\end{array}$ & $\begin{array}{l}\text { Truman Capote, } \\
\text { Breakfast at } \\
\text { Tiffany's } \\
\text { Lawrence } \\
\text { Ferlinghetti, } \\
\text { A Coney Island of } \\
\text { the Mind } \\
\text { Jack Kerouac, The } \\
\text { Subterraneans and } \\
\text { The Dharma Bums } \\
\text { Bernard Malamud, } \\
\text { The Magic Barrel } \\
\text { Vladimir Nabokov, } \\
\text { Lolita (US } \\
\text { publication; France } \\
\text { 1955) }\end{array}$ & $\begin{array}{l}\text { Flower Drum Song } \\
\text { (600 performances) } \\
\text { Archibald McLeish, } \\
\text { J.B. } \\
\text { Eugene O'Neill, } \\
\text { Hughie first } \\
\text { performed } \\
\text { Tennessee Williams, } \\
\text { Suddenly Last } \\
\text { Summer }\end{array}$ \\
\hline 1959 & $\begin{array}{l}\text { Nikita Krushchev and } \\
\text { Richard Nixon in live } \\
\text { televised 'kitchen } \\
\text { debate' from } \\
\text { Moscow. } \\
\text { IBM put first } \\
\text { transistorised } \\
\text { computer on the } \\
\text { market. } \\
\text { Soviet spacecraft } \\
\text { photographs far side } \\
\text { of the moon. } \\
\text { Buddy Holly and } \\
\text { Ritchie Valens die in } \\
\text { plane crash. } \\
\text { Frank Lloyd Wright's } \\
\text { Guggenheim Museum } \\
\text { completed. }\end{array}$ & $\begin{array}{l}\text { William J. Buckley } \\
\text { Jr, Up From } \\
\text { Liberalism } \\
\text { Norman O. Brown, } \\
\text { Life Against Death } \\
\text { Norman Mailer, } \\
\text { Advertisements for } \\
\text { Myself } \\
\text { C. Wright Mills, } \\
\text { The Sociological } \\
\text { Imagination } \\
\text { Paul Tillich, } \\
\text { Theology of Culture }\end{array}$ & $\begin{array}{l}\text { Saul Bellow, } \\
\text { Henderson the Rain } \\
\text { King } \\
\text { William Burroughs, } \\
\text { Naked Lunch } \\
\text { Philip Roth, } \\
\text { Goodbye, Columbus } \\
\text { Jack Kerouac, } \\
\text { Mexico City Blues } \\
\text { Robert Lowell, Life } \\
\text { Studies }\end{array}$ & $\begin{array}{l}\text { Edward Albee, The } \\
\text { Zoo Story } \\
\text { (performed in West } \\
\text { Berlin) } \\
\text { Lorraine Hansberry, } \\
\text { A Raisin in the Sun } \\
\text { Allan Kaprow, } 18 \\
\text { Happenings in } 6 \\
\text { Parts, Reuben } \\
\text { Gallery } \\
\text { Tennessee Williams, } \\
\text { Sweet Bird of Youth } \\
\text { The Sound of Music } \\
\text { (1,443 performances) }\end{array}$ \\
\hline
\end{tabular}




\begin{tabular}{llll}
\hline Film & Television & Music
\end{tabular}

Cat on a Hot Tin Roof (Richard Brooks) The Defiant Ones (Stanley Kramer) Imitation of Life (Douglas Sirk) The Naked and the Dead (Raoul Walsh) Vertigo (Alfred Hitchcock)
The Donna Reed Show (1958-66)

Naked City (1958-63)

Peter Gunn (1958-61)

77 Sunset Strip

(1958-64)

Twenty-One scandal and end of highjackpot quiz shows
Chuck Berry, 'Sweet Little Sixteen' Phil Spector, 'To Know Him Is to Love Him' South Pacific and Gigi soundtracks top sellers First commercial stereo recordings released Newport Jazz Festival filmed and released in 1959 as Jazz on a Summer's Day
Robert Frank, The Americans

Louise Nevelson, Sky

Cathedral

Bruce Conner, A Movie Jasper John's first solo exhibition, Leo Castelli Gallery Mark Rothko paints murals for the new Seagram Building
Anatomy of a Murder (Otto Preminger)

The Manchurian Candidate (Richard Condon)

North By Nortbwest

(Alfred Hitchcock)

Pillow Talk (Michael

Gordon)

Some Like It Hot

(Billy Wilder)
Bonanza (1959-73)

Hawaiian Eye

(1959-63)

Rocky and His Friends (1959-61)

The Twilight Zone (1959-65)

The Untouchables (1959-63)
John Cage, Indeterminacy

Ray Charles, 'What'd I Say' Lloyd Price, 'Stagger Lee' Mountain Music Bluegrass Style Star and Motown labels make their debut
Robert Frank, Pull My Daisy Edward Kienholz, John Doe (1959) and Jane Doe (1960) Frank Stella begins his Black Paintings Harold Rosenberg, The Tradition of the New

'New Images of Man' exhibition, MoMA 
